\title{
Analysis of Factors Affecting Implementation of Entity Financial Accounting Standards without Public Accountability (SAK ETAP) in Middle Small Micro Businesses (UMKM) District in Indragiri District Region
}

\author{
Yusriwarti and Ira Gustina \\ Prodi Akuntansi, Fakultas Ekonomi. Universitas Islam Indragiri, \\ yusriwarti9@gmail.com, iragustina310885@gmail.com
}

\begin{abstract}
This study aims to determine and empirically test the effect of providing information and outreach, educational background and business scale on the understanding of MSMEs in preparing financial reports based on SAK ETAP at MSMEs Tembilahan District, Indragiri Hilir Regency, Riau. The sample of this study were 63 MSMEs in the gold, cellphone, drug and electronic trading sectors in Tembilahan District, Indragiri Hilir Riau District. Data collection techniques used the Surver Method. This study uses the data analysis method of Multiple Linear Regression using SPSS Version 26. Partial hypothesis test results show that the provision of information and socialization have no effect on MSME understanding in preparing financial reports based on SAK ETAP on MSMEs Tembilahan District, Indragiri Hilir Riau District, educational background influences the understanding of MSMEs in preparing financial reports based on SAK ETAP at UMKM Tembilahan District, Indragiri Hilir Riau District, and the business scale influences the understanding of MSMEs in preparing financial reports based on SAK ETAP on MSMEs Tembilahan District, Indragiri Hilir Riau Regency. Hypothesis test results simultaneously providing information and outreach, educational background and business scale simultaneously affect the understanding of MSMEs in preparing financial reports based on SAK ETAP at MSMEs Tembilahan District, Indragiri Hilir Regency, Riau. The coefficient of determination of $43.8 \%$ shows that the understanding of MSMEs in preparing financial reports based on SAK ETAP at MSMEs Tembilahan District, Indragiri Hilir Riau District is influenced by the provision of information and socialization, educational background and business scale of $43.8 \%$, while the remaining $56,2 \%$ is influenced by other variables not examined in this study.
\end{abstract}

\section{Keywords}

Provision of Information and Socialization, Educational Background, Business Scale, Understanding of MSMEs in Preparing Financial Statements Based on SAK ETAP

\section{Introduction}

Micro, Small and Medium Enterprises (MSMEs) is one of the economic activities that is mostly carried out by the people of Indonesia. The existence of Micro, Small and Medium Enterprises (MSMEs) must be supported and encouraged by their ability to continue to grow and live, so that they can expand business opportunities and expand employment, Micro, Small and Medium Enterprises (MSMEs) have an important role in the country's economic growth, for developed countries or developing country (Nandani and Mahendra 2016).

Four main problems faced by Micro, Small and Medium Enterprises (MSMEs) in Indonesia, especially in facing the 2015 ACFTA era. First, problems related to the preparation of financial statements. Second, problems related to capital. Third, problems related to mastery of technology and fourthly issues related to the marketing of products and services of Micro, Small and Medium Enterprises (MSMEs). From these problems, which are often faced by Micro, Small and Medium Enterprises (MSMEs) are problems in preparing financial statements (Nurvelin 2019). Republic of Indonesia Government Regulation Number 17 of 2013 concerning the implementation of Law Number 20 of 2008 concerning Micro, Small and Medium Enterprises (MSMEs). In this case the government has enacted legislation for Micro, Small and Medium Enterprises (MSMEs) in recording financial statements. Knowledge and skills are very necessary in understanding SAK ETAP. Provision of information and outreach is an alternative that can be used to provide knowledge and understanding to SMEs in order to prepare financial reports based on SAK ETAP. 
Presentation of financial statements based on SAK ETAP (Hidayat 2015) concerning the presentation of financial statements fairly into subdivisions, as follows:

1. Fair presentation

2. Compliance with SAK ETAP

3. Business continuity

4. Frequency of reporting

5. Consistent presentation

6. Comparative information

7. Materiality and aggregation

8. Complete financial statements

9. Identification of financial statements

This study aims to determine and empirically test the effect of providing information and outreach, educational background and business scale on the understanding of MSMEs in preparing financial reports based on SAK ETAP at MSMEs Tembilahan District, Indragiri Hilir Regency, Riau. Data collection procedures of this study used primary data by distributing questionnaires and secondary data, where the questionnaire was measured using a nominal scale and a Likers scale. Secondary data in this study are data needed to support research results derived from journal literature and books that are relevant to research.

\section{Literature Review}

\section{Quality of Financial Statements}

The Financial Accounting Standards Board (DSAK) has compiled and published Financial accounting standards as a guide for MSMEs in preparing financial reports namely Financial Accounting Standards for Entities Without Public Accountability (SAK ETAP). Own financial statements are products resulting from the accounting process, according to (Rudiantoro and Sylvia Veronica 2012) is a report provided by the information system for stakeholders regarding economic activity and company conditions. Quality financial reports for MSMEs can be generated if they are in the preparation process and the accounting process conducted according to standards applicable. In Indonesia alone before enactment of SAK ETAP, a standard that is applied to serve as guidelines in the accounting process for a business entity is PSAK. Because PSAK is still too much common to business entity criteria, SAK ETAP was published. In implementation of business entities that are not having public accountability can still be choose which standard will be made guidelines for preparing reports finance, can use SAK ETAP or public PSAK (Farina and Sri 2016).

The Financial Accounting Standards Board (DSAK) has prepared and issued financial accounting standards as a guide for MSMEs in preparing financial statements namely Financial Accounting Standards for Entities Without Public Accountability (SAK ETAP) as of January 1, 2011. An Entity without Public Accountability (ETAP) is an entity that does not has significant public accountability, and does not issue financial statements for its purposes general (general purpose financial statement) for external users. If compared to IFRS the ETAP standard is made simpler so it's easier understood and implemented by SMEs (Rahmawati and Puspasari 2016) stated the criteria entity without its own public accountability developed by comparing it with the meaning of the entity that owns public accountability, namely: first, the entity has submitted a registration statement or entity in the submission process statement of registration with the market authority capital (BAPEPAM-LK) or other regulators for the purpose of issuing securities in the capital market and second, the entity controls the assets within capacity as fiduciary for a group large communities, such as banks, entities insurance, broker and / or securities trader, pension funds, mutual funds and investment banks. SMEs do not necessarily directly implement SAK ETAP within preparation of financial statements even though SAK ETAP already offers many and benefits and convenience. In fact, there are still many who have not carried out activities bookkeeping and accounting processes in managing economic transactions that occur in the uni this effort. Several factors allegedly caused the people's reluctance, including: low education level, lack of knowledge and expertise related to accounting, lack of experts who can do the bookkeeping process according to standards, perceptions which considers that bookkeeping activity is not important to the company, complexity in the accounting process that causes them to still not separate personal funds and funds used for business (Kurniawati, Nugroho, and Arifin 2012)(Hutagaol, 2012).

MSMEs do not immediately implement SAK ETAP in preparation of financial reports even though SAK ETAP already offers many and benefits and convenience. In fact, there are still many who have not done activities 
bookkeeping and accounting processes in managing economic transactions that occur in the unit his efforts. Quality financial reports for MSMEs can be produced if they are in process the preparation and accounting processes carried out are adjusted to the applicable standards. The criteria for entities without public accountability are developed by comparing them by means of entities that have public accountability.

\section{Micro, Small and Medium Enterprises (MSMEs)}

Micro, Small and Medium Enterprises (UMKM) is a business consisting of micro, small and medium enterprises that have met certain criteria based on the law that has been established. Micro, Small and Medium Enterprises (MSMEs) aim to grow and develop their businesses in order to build a national economy based on just economic democracy (Law 20 of 2008 article 3). Most of the UMKM players carry out business activities for the sole purpose meet the needs of everyday life. Meeting the daily needs is considered as a business success. UMKM actors do not want to do bookkeeping financial transactions carried out. UMKM players who tend to run a business for fulfillment of needs and do not desire to expand their business. Most of the MSMEs only use capital that comes from themselves and the owner, rotation on the results of the business obtained, so that the business developed is only limited to the level only owned capital (Alhusain, 2009).

The population in this study is the MSMEs engaged in the trade sector in Tembilahan Subdistrict, Indragiri Hilir Riau Regency. The sample in this study were SMEs engaged in the gold, drug, electronic and mobile phone trading sectors. The Financial Accounting Standards Board (DSAK) has compiled and issued it financial accounting standards as a guide for MSMEs in preparing financial statements namely Financial Accounting Standards for Entities Without Public Accountability (SAK ETAP) as of January 1, 2011. An Entity without Public Accountability (ETAP) is an entity that does not has significant public accountability, and does not issue financial statements for its purposes general (general purpose financial statement) for external users. If compared to IFRS the ETAP standard is made simpler so it has easier understood and implemented by SMEs.

The purpose of preparing financial statements based on SAK ETAP is to provides information about the company's financial position, financial performance and reports an entity's cash flow which is beneficial for a large number of users in making economic decisions by anyone who is not in a position can ask for financial statements specifically to meet certain information needs.

SMEs do not necessarily directly implement SAK ETAP within preparation of financial statements even though SAK ETAP already offers many and benefits and convenience. In fact, there are still many who have not carried out activities bookkeeping and accounting processes in managing economic transactions that occur in the unit his effort. Several factors allegedly caused the people's reluctance, including: low education level, lack of knowledge and expertise related to accounting, lack of experts who can do the bookkeeping process according to the standard, perception which considers that bookkeeping activity is not important to the company, complexity in the accounting process that causes them to still not separate personal funds and funds used for business (Baas and Schrooten 2006). Financial statements are the output that results from the accounting process. Accounting according to (Muharlisiani et al. 2019) is a report provided by information systems for stakeholders regarding economic activities and company conditions. Data collection procedures of this study used primary data by distributing questionnaires and secondary data, where the questionnaire was measured using a nominal scale and a Likers scale. Secondary data in this study are data needed to support research results derived from journal literature and books that are relevant to research. Socialization as a process of a person acquiring the knowledge, skills and attitudes he treats in order to function as an adult and at the same time be an active actor in a particular position or role in society. With the provision of information and socialization regarding the preparation of financial statements based on SAK ETAP, a competent understanding of the preparation of financial reports based on SAK ETAP will be better and support the process of implementing SAK ETAP for Micro, Small and Medium Enterprises (MSMEs). How many Micro, Small and Medium Enterprises (MSMEs) actors get information and take part in socialization related to financial reports based on SAK ETAP. The more Micro, Small and Medium Enterprises (MSMEs) get information and follow the socialization about SAK ETAP, the better the knowledge of Micro, Small and Medium Enterprises (MSME) entrepreneurs about SAK ETAP and the better the financial reporting of Micro, Small and Medium Enterprises (UMKM) because they have been able to implement SAK ETAP (Rahmawati and Puspasari 2017).

\section{Banking Capital}

A bank is an institution that raises funds, accordingly regulations, from the community and channel it back to the community through credit or other forms that drive the economy. Based on this concept, the Bank collects funds 
owned by the people and distributes it to the people as well so that they become intermediary institutions (intermediary institutions). Bank managing public assets and these public funds must be withdrawn immediately or at maturity. This means that there is a risk that occurs in the bank's business where borrowers of funds cannot return funds obtained (borrowed) from banks and investors (depositors of funds) also have the risk of not being able to return their funds.The most important factor of production needed in the production process is capital, which is a factor of production important for the procurement of factors of production like soil, raw materials, and machinery. Capital in a company is managed in various forms according to needs and goals to be achieved, include: (1) land purchase and building; (2) purchase of material inventory; (3) purchase of machinery and equipment; and (4) the remainder is saved in cash cash / cash (Baas and Schrooten 2006).

Understanding the concept of a bank, then bank capital starts with deposits capital and then develop into a large where the owner of the funds keeps the funds on deposits (often called Depositor). Both capitals are loaned by the bank to the parties others and banks must also be on guard or prepare funds if the Depositors briefly withdraw the funds. If the bank does not have funds, the bank must make a loan from the bank others who have funds and the bank returns them after getting funds from the depositor. As a result, banks may experience a negative spread in carrying out these activities so that they are a going concern banks are running and depositors' confidence remains high.

Increased production by a business unit will make more the large business development can also have an impact on expanding share market. With the availability of capital then business activities will run smoothly so that, or it can be said of capital development itself occurs through a process of activity effort. The source of capital used by the company can be obtained from owned capital from the owner entirely or is a combination of own capital with foreign capital. Own foreign capital can be obtained from investors as well loans from other parties (banks) (Wibowo and Kurniawati 2016). The growth of micro, small and medium enterprises (MSMEs) requires capital is not small, therefore this opportunity is captured by Islamic banks through financing. Financing is the most effort to channel funds large numbers of bank financial institutions (Karim, 2010) are full of risks a sizeable loss (Afkar, 2015), but also has opportunities big in making a profit.

\section{Scale Enterprises}

Business in a form that has a legal entity or not components of economic actors. Economic actors with various kinds of businesses in the end will contribute to national income with there is economic growth. Business in the scope of micro, small and medium (UMKM) is a form of business that can move the macro economy by leading to changes in income levels and community welfare. The form of MSME can be a company individuals, alliances, like for example firm and CV, as well as a limited liability company. MSMEs can be categorized into three mainly based on the number of assets and turnover as stated in the Act - Law Number 20 Year 2008 concerning MSMEs as follows: Micro Business: Own productive business individuals and / or business entities individuals who meet the criteria as follows:

- Assets $\leq$ Rp.50,000,000.00 Has less net worth from or equal to Rp.50,000,000.00 (fifty million rupiah).

- Turnover $\leq$ Rp300,000,000.00 Has annual sales results less than Rp. 300,000,000.00 (three hundred million rupiah)

Small Business: Economic business productive stand-alone, who done by individuals or business entity which is not constituted a subsidiary or not a branch company owned, controlled, or become a good part right away or indirectly from business medium or large business ones meet the following criteria:

- Rp.50,000,000.00<Assets $\leq$ Rp.500,000,000.00 Have more net worth from Rp.50,000,000.00 (fifty million rupiah) up to the most a lot of Rp.500,000,000.00 (five hundred million rupiah) not included land and building premises effort); or

- Rp. 300,000,000.00<Turnover $\leq 2,500,000,000.00$ Has annual sales results more than Rp. 300,000,000.00 (three hundred million rupiah) up to most widely Rp2,500,000,000.00 (two billion five hundred million).

Medium Business: Economic business productive stand-alone, who done by individuals or business entity which is not constituted a subsidiary or branch company owned, controlled, or become a good part right away or indirectly with the business small or large businesses that meet

criteria as follows: 
- Rp500,000,000.00<Assets $\leq$ Rp.10,000,000,000.00 Have more net worthfrom Rp.500,000,000.00 (five hundred million rupiah) up to most widely Rp10,000,000,000.00 (ten billion rupiah) not includedland and building premises effort; or

- Rp2,500,000,000.00 <Turnover $\leq \mathrm{Rp} \cdot 50,000,000,000.00$ Has annual sales results more than Rp2,500,000,000.00 (two billion five hundred million rupiah) up to the most Rp.50,000,000,000.00 (fifty billion rupiah).

\section{METHODS}

Primary data in this study the results of interviews and the questionnaire against the owner or 63 managers of the gold, drug, electronic and mobile phone trading sectors in Tembilahan District, Indragiri Hilir Riau Regency. The method used in sampling using convenience sampling. With $\mathrm{n}$ (amount sample) at least 30 (Apriyanto and Umanailo 2019). Data collection procedures in research This uses interviews and questionnaires. The interview process is carried out by the author with use depth interviews.

The steps of the analysis carried out is:

- Classifying data based on accounting records, accounting reporting and constraining business constraints SMEs in the application of accounting which has been obtained through semi interviews structured and questionnaire.

- Identifying records and accounting reporting of each classification.

- Analyzing the constraints faced by SMEs in applying accounting.

- Process data and make conclusions thoroughly based on data was obtained.

\section{Results and Discussion}

This study uses data sourced by distributing questionnaires to respondents, namely MSMEs engaged in the trade sector in Tembilahan District, Indragiri Hilir Riau Regency. MSMEs engaged in the gold, medicine, electronics and mobile phone trading sectors in Tembilahan District, Indragiri Hilir Riau Regency, were 63 respondents. The objects in this study are shops there are MSMEs engaged in the gold, medicine, electronics and mobile phone trading sectors in Tembilahan District, Indragiri Hilir Riau Regency, as many as 63 respondents. Who meet the criteria as MSME (Micro, Small and Medium Enterprises) accordingly law No.20 of 2008 concerning MSME. From various shops found at MSMEs engaged in the gold, medicine, electronics and mobile phone trading sectors in Tembilahan District, Indragiri Hilir Regency, Riau, were taken some samples that will be used as sources this research is to represent the population MSMEs in Tembilahan District, Indragiri Hilir Regency, Riau.

From 63 entrepreneurs surveyed, 6 refused to do interviews and questionnaires, 5 of the data invalid so 53 fulfilled the criteria will be further investigated. Most of the shops in Tembilahan Subdistrict, Indragiri Hilir Regency, Riau are dominated by small business (64.71\%). The small business mostly self-managed (84.3\%) with the manager's educational background most are graduate level High School (37\%). Application accounting includes recording and accounting reporting (Kurniawati, Nugroho, and Arifin 2012).

From table 1 shows that in part shopping center in Tembilahan District, Indragiri Hilir Regency, Riau keep a record of cash inflows and cash out (78,45\%). Most of which are only records cash in and cash out have a School education background Elementary to Middle School First (40\%) and High Schools up to Bachelor (60\%). Most (80.49\%) are only record cash in and cash out of the business self managed.

Table 1. Transactions Recorded by MSMEs Managers

\begin{tabular}{|c|c|c|c|c|c|c|c|}
\hline \multirow[t]{3}{*}{ No } & \multirow{3}{*}{$\begin{array}{c}\text { That transaction } \\
\text { Recorded }\end{array}$} & \multicolumn{4}{|c|}{ Respondents } & \multicolumn{2}{|c|}{ Total Respondents } \\
\hline & & \multicolumn{2}{|c|}{ Note No. } & \multicolumn{2}{|c|}{ Take notes } & & \\
\hline & & Total & $\%$ & Total & $\%$ & Total & $\%$ \\
\hline 1 & Sales & 35 & 67,66 & 18 & 32,34 & 53 & 100 \\
\hline 2 & Purchase & 49 & 94,23 & 4 & 5,77 & 53 & 100 \\
\hline 3 & Stock & 29 & 55,77 & 24 & 44,23 & 53 & 100 \\
\hline 4 & Cash in & 40 & 78,56 & 13 & 21,44 & 53 & 100 \\
\hline 5 & Cash out & 39 & 78,45 & 14 & 21,65 & 53 & 100 \\
\hline 6 & Cost & 30 & 57,69 & 23 & 42,31 & 53 & 100 \\
\hline 7 & Salary & 29 & 55,76 & 24 & 44,23 & 53 & 100 \\
\hline
\end{tabular}

Source: Primary data processed 
There are 10 respondents (19.6\%) who did not only record cash in and cash out, as well as only record sales, purchases, costs and salary. In the opinion of the manager, they are only records cash in and cash out it is sufficient to run his effort. If cash in is greater rather than cash out means profit. There were 11 respondents (21.57\%) doing recording sales transactions, purchases, inventory and costs. Only 8 respondents (19.51\%) which recorded sales, purchases, costs, salaries and business are managed alone. Assuming that noted sales, purchases, supplies, and transactions costs can know more clearly profit or business loss. Most of which are record sales, purchases, inventory and costs have a background education above junior high school (70\%). On the recording of salaries, out of 53 there were 8 respondents who did not have employees (15.7\%). Of 45 only 26 respondents have employees respondents (53.33\%) who recorded salary, which have employees but don't record salaries assume that the salary has been entered in cash out. There are 9 respondents (17.65\%) whose recording system is computerized. The system manager computerized records have a background behind education above school First Intermediate. The managers have assuming that by using the system computerized will be able to reduce risk of miscalculation in inventory (Prawesti 2017).

Based on information from tables 2 shows that for the most part respondents make sales reports (66.67\%) and purchase reports (52.94\%). That is due to the notion that the main activity in the shop business is on sales and purchases. Some that makes a great sales report and purchase has a background High school education. All respondents who make an inventory report definitely make a sales report and report purchase. According to the manager's assumption business shop inventory reports can be made when there are sales reports and purchase. By counting the amount initial inventory plus purchases less the amount of goods sold the remaining goods that can be sold are known.

Most respondents (60.78\%) did not make a salary report. The managers who have employees and make salary reports there are 21 respondents (46.67\%). From 24 respondents who record payroll, 21 respondents (87.5\%) also payroll reporting. There are 6 respondents $(11.76 \%)$ who do not have employees, so directly also do not do recording salaries and not making reports payroll. Shop business managers assume that with the report payroll will make it easier in decision making whether to increase or decrease the amount the employee (Rahmawati and Puspasari 2017).

Most business managers make sales, purchase and inventory reports every day. Shown in business ventures handphone, from 10 respondents 7 (70\%) including recording every sales report the day, 4 respondents (40\%) made a report purchase and inventory reports each the day. For salary reports, from 20 respondents who make salary reports, 17 (85\%) of them do salary reporting each month. Most reporting purposes conducted by shop managers on the street Tembilahan District, Indragiri Hilir Regency is for management business (66.67\%). There are still quite a lot of them did not make a business report (15.69\%). Who does not make business reporting, most only take notes cash in and cash out only. According to opinions of 7 respondents (13.52\%), Accounting reporting is not required for businesses that don't have a sales system certainty of the selling price, if there is a difference from cash in and cash out means profit effort. There are 6 respondents (11.76\%) who reporting tax sales, 4 among them (66.67\%) entered the business category intermediate.

Table 2. Reports Made by MSME Managers

\begin{tabular}{|c|c|c|c|c|c|c|c|c|c|c|}
\hline \multirow[t]{2}{*}{ No } & \multirow{2}{*}{$\begin{array}{l}\text { Report which } \\
\text { Was made } \\
\text { Respondents }\end{array}$} & \multicolumn{2}{|c|}{ Make } & \multicolumn{2}{|c|}{ Not making } & \multicolumn{2}{|c|}{$\begin{array}{c}\text { Total } \\
\text { Respondens }\end{array}$} & \multicolumn{3}{|c|}{ Periods } \\
\hline & & Total & $\%$ & Total & $\%$ & Total & $\%$ & days & week & mount \\
\hline 1 & Report Sales & 43 & 81,13 & 10 & 18,87 & 53 & 100 & 26 & 2 & 6 \\
\hline 2 & Report Purchase & 20 & 37,73 & 33 & 62,27 & 53 & 100 & 17 & 6 & 6 \\
\hline 3 & Report Stock & 26 & 29,05 & 27 & 70,95 & 53 & 100 & 15 & 4 & 11 \\
\hline 4 & Salary Report & 40 & 76,92 & 13 & 23,08 & 53 & 100 & 19 & 7 & 20 \\
\hline
\end{tabular}

Source: Primary data processed

From this study obstacles are hindering The UMKM is in the application of accounting is in terms of capabilities which include Educational background and expertise less owner or manager owned memadahi, so the lack of understanding the importance of accounting in management effort. This is shown by most business managers (37.25\%) at the level High School and at the level Junior High School (25.49\%). Most of the store business 
Proceedings of the 5th NA International Conference on Industrial Engineering and Operations Management Detroit, Michigan, USA, August 10 - 14, 2020

managers (94.12\%) never attended training accounting. And a small proportion (5.88\%) are had attended accounting training is come from SMK, especially in the field Accounting. Most (90.20\%) owners or store manager does not need accounting training.

Business scale variables influence the understanding of MSMEs in preparing financial statements based on SAK ETAP. This shows that the increasing growth of a Micro, Small and Medium Enterprises (MSMEs), the need for financial reports in accordance with accounting standards will be higher. Micro, Small and Medium Enterprises (MSMEs) of Tembilahan District in the gold, drug, electronic and cellphone trading sectors that have large or small assets and turnover, they have implemented a good financial statement preparation in accordance with applicable accounting standards, where they realize that financial statements are very important for their business. With a good financial report, they can provide accurate information to interested parties such as applying for bank credit, the MSME can provide information to the bank that their business is in good condition with the evidence of their business financial statements. Micro, Small and Medium Enterprises (MSMEs) that do not have financial reports in accordance with financial accounting standards, it is likely that they have difficulty in obtaining loans or it is difficult to provide accurate information to interested parties.

Understanding in preparing financial statements is still fairly low, where there are some of those SMEs who still use traditional methods in preparing their business financial statements and only present or make financial reports in the form of cash in and cash out only. From all business managers, they have already have notes and reports, but no one has yet made a profit report losses, changes in capital and balance sheet.

\section{Conclusion}

Providing information and socialization, educational background and business scale together influence the understanding of MSMEs in preparing financial reports based on SAK ETAP at MSMEs Tembilahan District, Indragiri Hilir Riau District.

\section{References}

Afkar, Taudlikhul. 2015. Pengaruh Risiko Kredit Terhadap Kecukupan Modal Perbankan Syariah di Indonesia. Ekosiana. Vol.2 No 2, Maret 2015.

Alhusain, Achmad Sani. 2014. Analisa Kebijakan Permodalan Dalam Mendukung Pengembangan Usaha Mikro Kecil dan Menengah (Studi Kasus Provinsi Bali Dan Sulawesi Utara). Kajian Vol 14 No.4.

Apriyanto, Mulono and M Chairul Basrun Umanailo. 2019. "Decrease Polyphenols, Ethanol, Lactic Acid, and Acetic Acid during Fermentation with Addition of Cocoa Beans Innoculum.” International Journal Of Scientific \& Technology Research 8(10): 461-65. www.ijstr.org.

Baas, Timo, and Mechthild Schrooten. 2006. "Relationship Banking and SMEs : A Theoretical Analysis *." Small Business Economics 27: 127-37.

Farina, Khoirina, and Opti Sri. 2016. "Kualitas Laporan Keuangan Umkm Diwilayah Jakarta Timur." KESEJAHTERAAN SOSIAL Journal of Social Welfare 6(1): 59-71.

Hidayat, Muhammad. 2015. "Analisis Tingkat Pemahaman Dalam Menyusun Laporan Keuangan Berdasarkan Sak Etap Pada Umkm Di Kecamatan Sekupang Batam.” Jurnal Measuremen 9(3): 77-89.

Karim, Adiwarman. 2010. Bank Islam Analisis Fiqih dan Keuangan. Jakarta : PT. Raja Grafindo Persada.

Kurniawati, Elisabeth Penti, Paskah Ika Nugroho, and Chandra Arifin. 2012. "Penerapan Pencatatan Dan Laporan Akuntansi Pada Usaha Mikro Kecil Dan Menengah (UMKM).” Informatics and Business Institute Darmajaya 10(2): 1-10.

Muharlisiani, Lusy Tunik et al. 2019. "Public Relations Management Through Management By Objective.” International Journal of Scientific \& Technology Research 8(10): 1993-97.

Nandani, Aprillia Ayu, and Deny Mahendra. 2016. "Faktor-Faktor Yang Mempengaruhi Pemahaman Penyusunan Laporan Keuangan Berbasis Sak Etap Pada Usaha Mikro Kecil Menengah (Umkm) Pengrajin Batik Di Kecamatan Laweyan Surakarta.” Aktual 2(1): 141-57.

Nurvelin, Ervina. 2019. "Penerapan Laporan Keuangan Menggunakan Basis Kas Pada Rental Motor Lestari Malang.” Agregat 4(1): 1-6.

Prawesti, Ita. 2017. "Faktor-Faktor Yang Mempengaruhi Pemahaman UMKM Dalam Laporan Keuangan Berdasarkan SAK ETAP.” In , 1689-99.

Rahmawati, Teti, and Oktaviani Rita Puspasari. 2016. "Mengungkap Kesiapan Implementasi Sak Etap Dalam Menyajikan Laporan Keuangan Umkm Di Kabupaten Kuningan.” Prosiding SNaPP2016 Sosial, Ekonomi, 
Proceedings of the 5th NA International Conference on Industrial Engineering and Operations Management Detroit, Michigan, USA, August 10 - 14, 2020

dan Humaniora 4(1): 532-39.

Implementasi Sak Etap Dan Kualitas Laporan Keuangan Umkm Terkait Akses Modal Perbankan. Jurnal Kajian Akuntansi, 1(1): 49-62, 2017.

Rudiantoro, Rizki, and Siregar Sylvia Veronica. 2012. "Kualitas Laporan Keuangan Umkm Serta Prospek Implementasi Sak Etap.” Jurnal Akuntansi dan Keuangan Indonesia 9(1): 1-21.

Wibowo, Alex, and Elisabeth Penti Kurniawati. 2016. "Pengaruh Penggunaan Informasi Akuntansi Terhadap Keberhasilan Usaha Kecil Menengah (Studi Pada Sentra Konveksi Di Kecamatan Tingkir Kota Salatiga).” Jurnal Ekonomi dan Bisnis 18(2): 107.

\section{Biography}

Yusriwarti is a lecturer in economics with expertise in accounting. research conducted in accordance with the expertise and expertise in the field of accounting reports

Ira Gustina is a lecturer in economics with expertise in accounting. research conducted in accordance with the expertise and expertise in the field of accounting reports 